\title{
The binding properties of some novel ruthenium (III) complexes with human serum transferrin
}

\author{
A. L. Arsene', V. Uivarosi', N. Mitrea', C. M. Dragoi', A. Nicolae ${ }^{1}$ \\ ${ }^{1}$ Department of Biochemistry of University of Medicine and Pharmacy «Carol Davila», Faculty of Pharmacy \\ $6^{\text {th }}$ Traian Vuia St., 020956, Bucharest, Romania \\ ${ }^{2}$ Department of Inorganic Chemistry of University of Medicine and Pharmacy «Carol Davila», Faculty of Pharmacy \\ $6^{\text {th }}$ Traian Vuia St., 020956, Bucharest, Romania \\ andreeanitulescu@hotmail.com
}

\begin{abstract}
Aim. The transferrin cycle gained increased interest in recent years and it holds promise as an attractive system for strategies of drug targeting to tumors. Neoplasic cells exhibit a large demand of iron and therefore express highly transferrin receptors. As a consequence, transferrin conjugates can preferentially interact with cancer cells. This strategy is exploited nowadays for targeting novel anti-cancer drugs. Recent data showed that ruthenium (III) compounds possess antitumor and antimetastatic effects, due to their affinity for crucial biomolecules (like transferrin). Methods. The paper presents the transferrin-binding properties of some novel ruthenium (III) complexes with general formula $\mathrm{Ru}_{2}(\mathrm{DMSO})_{m} \mathrm{Cl}_{3} \cdot n \mathrm{H}_{2} \mathrm{O}$ ((Ru-nf) $\mathrm{L}$ : norfloxacin (nf), $m=1, n=1$; (Ru-cpx) L: ciprofloxacin (cpx), $m=2, n=2$; (Ru-oflo) L: ofloxacin (oflo), $m=1, n=1$; (Ru-levo) L: levofloxacin (Levo), $m=2, n=8$; (Ru-pip) L: pipemidic acid (pip), $m=1, n=2$, DMSO: dimethylsulfoxide). We investigated, in vitro, the interactions of these ligands with human transferrin through spectroscopic techniques, with the ultimate goal of preparing adducts with good selectivity for cancer cells. Results. All studied complexes interact with human serum transferrin; the molar ratio [complex]/[transferrin] strongly influences the binding affinity. Conclusions. The best interaction between the complexes studied and transferrin is achieved for a molar ratio of 8 ; the best interaction was registered for Ru-pip, followed by Ru-nf.
\end{abstract}

Keywords: ruthenium (III) complexes, transferrin.

Introduction. A number of biological studies have highlighted in the last years a novel mechanism of action for anticancer drugs, regardless their covalent binding with the DNA. The literature presents experimental evidence for an important affinity between the chemotherapeutic medicines and other crucial biomolecules like plasma proteins.

In this regard, transferrin became an interesting and promising biomolecule over the last years for the development of new biochemical mechanisms of drug targeting to tumor tissues [1-3]. Neoplasic cells demand

(C) Institute of Molecular Biology and Genetics NAS of Ukraine, 2011 high amounts of iron for their growth and therefore express the transferrin receptor at a high rate. As a consequence, transferrin conjugates can preferentially interact with cancer cells through transferrin receptors. This strategy is exploited nowadays for targeting novel anti-cancer drugs.

In the last years, following the success of cisplatin, several metal complexes other than platinum have been considered as possible alternatives. It was particularly found that ruthenium (III) compounds possess antitumor and antimetastatic activities [4]. Four classes of ruthenium (III) complexes were imposed as promising antitumor agents. Ammine-chloro derivatives comple- 


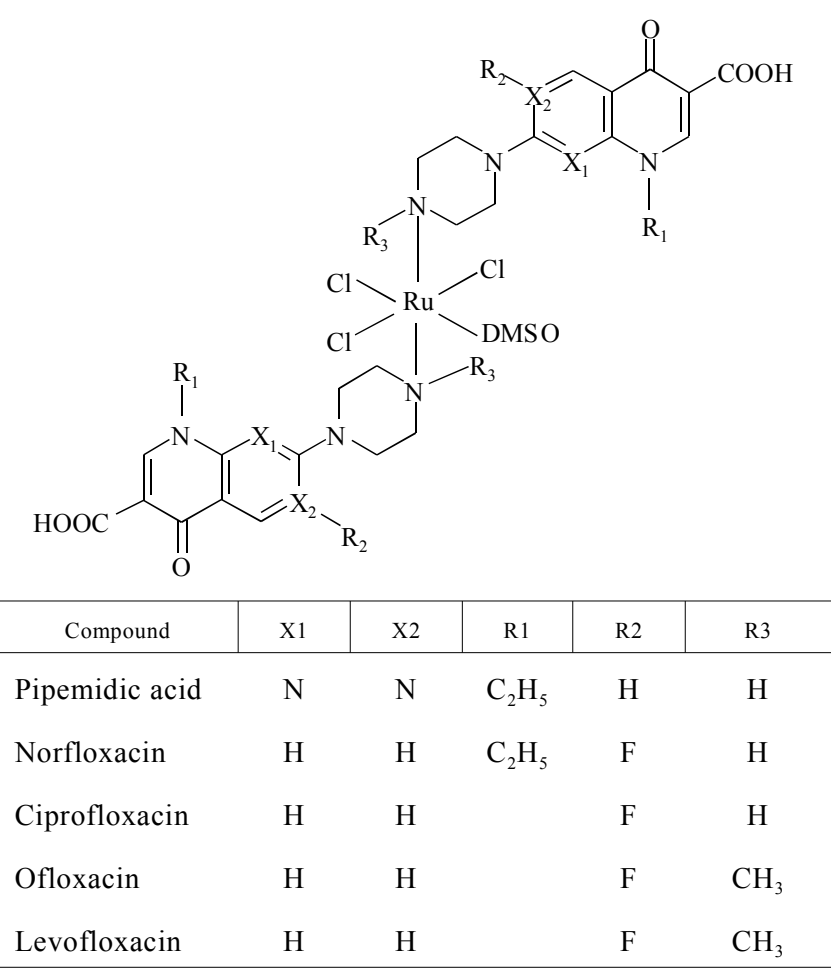

Fig. 1. Structures of the investigated quinolones and general structure of their $\mathrm{Ru}$ (III) complexes

xes like cis-[Ru(III) $\left.\left(\mathrm{NH}_{3}\right)_{4} \mathrm{Cl}_{2}\right]^{+}$and $f a c$ - $[\mathrm{Ru}(\mathrm{III})$ $\left(\mathrm{NH}_{3}\right)_{3} \mathrm{Cl}_{3}$ ] were developed by M. Clarke [5]. A large number of ruthenium (II) and ruthenium (III) mixed complexes with sulfoxide ligands were synthesized and characterized by the group of Alessio [6]. Between them, $\mathrm{Na}\left\{\right.$ trans $\left.^{-}\left[\mathrm{Ru}(\mathrm{III}) \mathrm{Cl}_{4}(\mathrm{DMSO})(\mathrm{Him})\right]\right\} \quad(\mathrm{Him}=$ = imidazole), nicknamed NAMI, and the more stable $\left[\mathrm{H}_{2} \mathrm{Im}\right]\left[\right.$ trans $\left.-\mathrm{Ru}(\mathrm{III}) \mathrm{Cl}_{4}(\mathrm{DMSO})(\mathrm{Him})\right]$, also known as NAMI-A are very promising [7]. Anionic ruthenium (III) complexes with heterocyclic nitrogen ligands of general formula $\mathrm{RuCl}_{4} \mathrm{~L}_{2}$ have been synthesized by Keppler et al. [8].

The derivatives with the formula trans$\left[\mathrm{RuCl}_{4}(\mathrm{~L})_{2}\right]^{-}$, where $\mathrm{L}$ is imidazole $(\mathrm{KP} 418)$ or indazole (KP1019 and KP1339), and the counterion (LH) ${ }^{+}$or $\mathrm{Na}^{+}$are very promising. KP1019 completed phase-I clinical trials [9].

Ruthenium polyaminocarboxylate complexes, a class of ruthenium (III) complexes with polydentate mixed donor ligands from the $\mathrm{H}_{4}$ EDTA family were prepared and tested by the group of Gonzalez-Vilchez [10].

The literature studies demonstrated the affinity of these complexes for transferrin and provide evidence for formation of stable adducts between them [11-16]. Therefore transferrin is investigated presently as a natural carrier of the drugs to the tumor tissue, mainly because of the high affinity of this iron-protein and the large number of transferrin receptors on the surface of tumor cells.

This paper presents the transferrin-binding properties of some novel ruthenium (III) complexes with mixed ligands of the type $\mathrm{RuL}_{2}(\mathrm{DMSO}){ }_{m} \mathrm{Cl}_{3} \cdot n \mathrm{H}_{2} \mathrm{O}$ ((Ru-nf) L: norfloxacin (nf), $m=1, n=1$; (Ru-cpx) L: ciprofloxacin (cpx), $m=2, n=2$; (Ru-oflo) L: ofloxacin (of), $m=1, n=1$; (Ru-levo) L: levofloxacin (Levo), $m=2, n=8$; (Ru-pip) L: pipemidic acid (pip), $m=1$, $n=2$, DMSO: dimethylsulfoxide) [17-20]. All complexes display an octahedral stereochemistry with the quinolone ligand acting as monodentate coordinated through N4 atom of piperazinyl ring. The structures of the ligands and the general structure of complexes are presented in Fig. 1.

Materials and methods. During the experiment the following reagents were used: Tris («Merck», Germany), serum transferrin («Merck»), working solutions of the studied ruthenium (III) complexes. The experimental procedure implied the following steps:

The first step implied the preparation of Tris buffer pH $7\left(5 \cdot 10^{-3} \mathrm{M}\right.$ Tris, $\left.5 \cdot 10^{-2} \mathrm{M} \mathrm{NaCl}\right)$.

The preparation of each of the ruthenium complexes stock solutions $10^{-5} \mathrm{M}$, using Tris buffer $\mathrm{pH} 7$ as solvent. When using this stock solution it was diluted 1:10 with Tris buffer (final complex working solution $\left.10^{-6} \mathrm{M}\right)$.

It was prepared a $10^{-5} \mathrm{M}$ stock solution of human serum transferrin in $\mathrm{pH} 7$ Tris buffer: in a $10 \mathrm{ml}$ volumetric flask $0.0077 \mathrm{~g}$ of human seric transferrin were weighed and disolved in $\mathrm{pH} 7$ Tris buffer. When using this stock solution it was diluted 1:10 with Tris buffer (final transferrin working solution $10^{-6} \mathrm{M}$ ).

For each studied complex we used 6 test tubes containing the reagents, as described in Table 1.

The test tubes (performed in triplicate) were incubated for 24 hours at room temperature, in the dark. Afterwards, the UV spectra $(\lambda=275 \mathrm{~nm})$ were immediately recorded using an UV-Vis Cary 100 Bio spectrophotometer («Varian Inc.», USA).

Results and discussion. In this study we conducted an extensive in vitro characterization of adducts 
Table 1

Working tehnique for studing the interactions of the studied complexes with transferrin

\begin{tabular}{l|c|c|c|c|c|c}
\multicolumn{1}{c}{ Reagents } & $\mathrm{P} 1$ & $\mathrm{P} 2$ & $\mathrm{P} 3$ & $\mathrm{P} 4$ & Transferrin blank & Complex blank \\
\hline AutoComplex solution, $10^{-6} \mathrm{M}$ & $1 \mathrm{ml}$ & $2 \mathrm{ml}$ & $4 \mathrm{ml}$ & $8 \mathrm{ml}$ & - & $4 \mathrm{ml}$ \\
Transferrin solution, $10^{-6} \mathrm{M}$ & $1 \mathrm{ml}$ & $1 \mathrm{ml}$ & $1 \mathrm{ml}$ & $1 \mathrm{ml}$ & $4 \mathrm{ml}$ & - \\
Molar ratio [complex]/[transferrin] & $1 / 1$ & $2 / 1$ & $4 / 1$ & $8 / 1$ & - & - \\
\hline
\end{tabular}

Table 2

Procentual decrease of the transferrin absorbance due to the interaction with the studied ruthenium complexes

\begin{tabular}{c|c|c|c|c|c}
\multirow{2}{*}{$\begin{array}{c}\text { Molar ratio } \\
{[\text { Ru-cx]/[transferrin }]}\end{array}$} & \multicolumn{5}{|c|}{ Procentual decrease of the transferrin absorbance due to the complex, \% } \\
\cline { 2 - 6 } & Ru-cpx & Ru-nf & Ru-oflo & Ru-pip & Ru-levo \\
\hline 1 & 0.118624 & 15.77699 & 12.93001 & 15.18387 & 13.04864 \\
2 & 10.32028 & 37.01068 & 30.60498 & 45.43298 & 31.55397 \\
4 & 12.81139 & 45.67023 & 43.89087 & 57.33096 & 37.84104 \\
8 & 17.55635 & 50.77106 & 44.72123 & 67.61566 & 45.90747 \\
\hline
\end{tabular}

between some possible ruthenium (III) drugs (newly synthesized) and human serum transferrin and we gained insight into the intriguing chemistry of these complexes. It is to mention that we also possess unpu lished data regarding the interactions of our newly synthesized ruthenium (III) complexes with human serum albumin (HSA) and DNA, but their affinity and binding to both HSA and DNA is importantly different, compared with the interactions with transferrin (from with the interaction stoichiometry to the reactivity patterns).

The present study evoked that there exists chemical binding between the substances investigated and transferrin and also that this interaction (including the chemical stoichiometry) is complicated and needs proper investigations in respect to their solution behaviour (reflected in the organisms fluids behaviour) and their protein binding ability. Nevertheless, the accurate knowledge of this binding (interaction) is crucial at this stage of the development of a newly possible antitumor drug since it directly reflects in the $\mathrm{IC}_{50}$ and toxicity.

The knowledge of the transferrin cycle has rapidly increased in recent years and it holds promise as an attractive system for strategies of drug targeting to tumor tissues. Indeed, tumor cells exhibit a large demand of iron for their growth and therefore express the transferrin receptor at a high rate. As a consequence, transferrin conjugates that retain a good affinity for the trans- ferrin receptor can preferentially interact with cancer cells. This strategy is exploited nowadays for targeting novel anti-cancer drugs. For example, Keppler's complexes were the first ruthenium (III) complexes whose interactions with human serum transferrin were investigated in solution by various techniques, including spectrophotometry, at different stoichiometry binding stages $[8,9,14]$. Also, such a strategy was used to achieve targeting on adriamycin to neoplastic tissues [2].

In our case, the major behaviour of our ruthenium (III) complexes reflected in the transferrin spectroscopic absorbance. In this regard transferrin absorbance in UV was modified (has decreased) in the presence of the studied ruthenium complexes, as it can be seen in Table 2 and Fig. 2-6.

The studied ruthenium complexes interact in vitro with transferrin. This fact has been experimentally observed by the diminish of the absorbance value of transferrin in UV, consequent to the direct contact complextransferrin.

By analyzing the obtained results, it can be concluded that the complex Ru-nf produces the most important decrease in the UV transferrin absorbance, when used in the molar ratio [Ru-nf] $/[$ transferrin $]=1 / 1$. The decrease in the UV absorbance of this protein due to an interaction with the research complexes (molar ratio [complex $] /[$ transferrin $]=1 / 1$ ) has varied as follows: Ru-nf $>$ Ru-pip $>$ Ru-levo $>$ Ru-oflo $>$ Ru-cpx. 


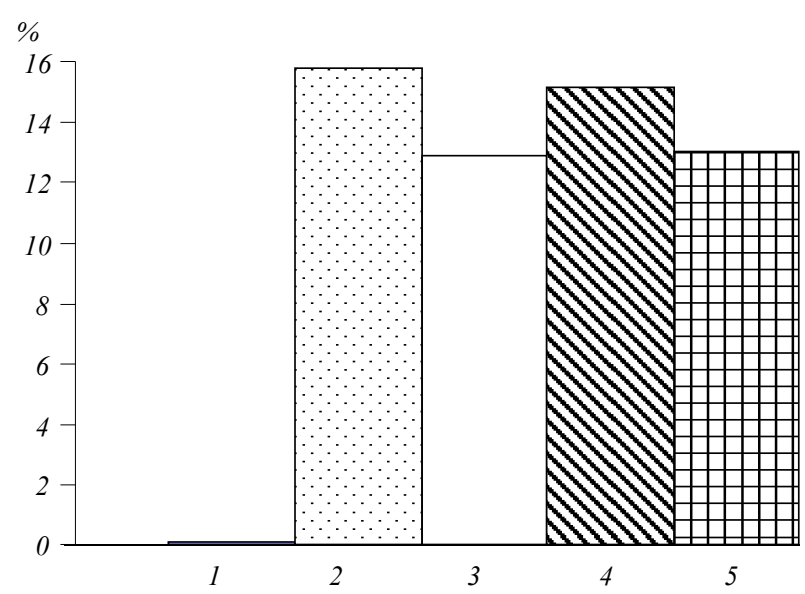

Fig. 2 Dynamics of human serum transferrin UV absorbance after the interaction with the studied complexes (molar ratio [complex]/[transferrin $]=1 / 1) ; y$ axis - absolute values of transferrin absorbance inhibition for a molar ratio of interaction $[$ complex $] /[$ transferrin $]=1 / 1$ : 1 - [transferrin]/[Ru-cpx]; 2 - [transferrin]/[Ru-nf]; 3 - [transferrin] $]$ [Ru-oflo]; 4 - [transferrin]/[Ru-pip]; 5 - [transferrin]/[Ru-levo]

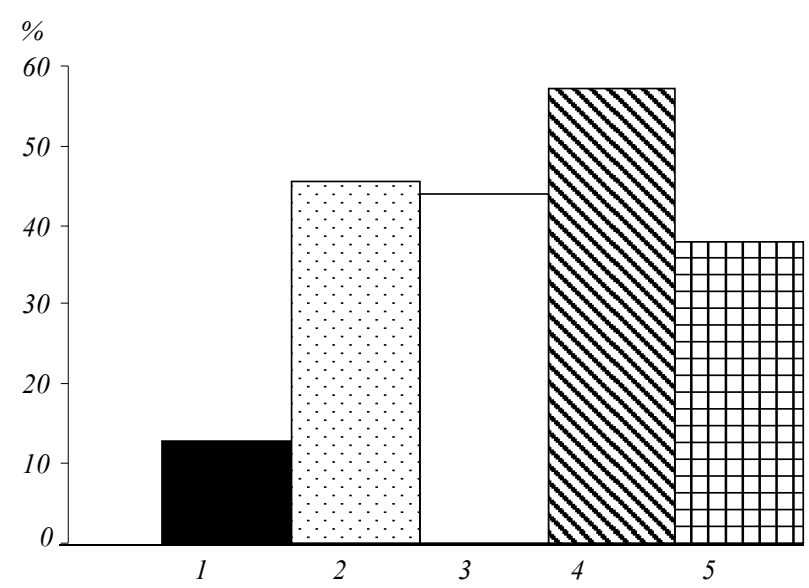

Fig. 4 Dynamics of human serum transferrin UV absorbance after the interaction with the studied complexes (molar ratio [complex]/[transferrin $]=4 / 1) ; y$ axis - absolute values of transferrin absorbance inhibition for a molar ratio of interaction $[$ complex $] /[$ transferrin $]=4 / 1$ : 1 - [transferrin]/[Ru-cpx]; 2 - [transferrin]/[Ru-nf]; 3 - [transferrin] [Ru-oflo]; 4 - [transferrin]/[Ru-pip]; 5 - [transferrin]/[Ru-levo]

When using the molar ratio [complex]/[transferrin] $=2 / 1$ it was observed, as well, a decrease of the UV absorbance of human serum transferrin, in vitro. The procentual dynamics of this phenomenon is: Ru-pip $>$ $>$ Ru-nf $>$ Ru-levo $>$ Ru-oflo $>$ Ru-cpx.

When using the molar ratio [complex]/[transferrin] $=4 / 1$ it was observed a decrease of the UV absorbance of human serum transferrin, in vitro. The pro-

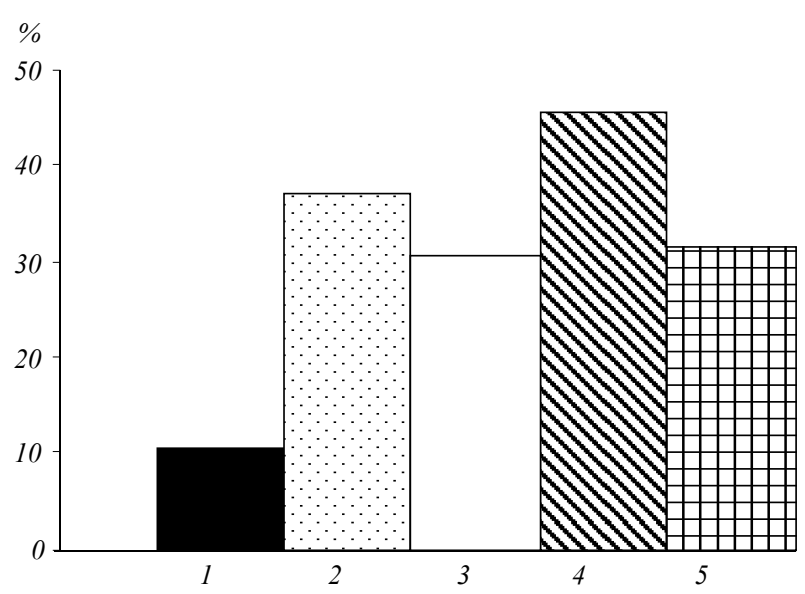

Fig. 3 Dynamics of human serum transferrin UV absorbance after the interaction with the studied complexes (molar ratio [complex]/[transferrin $]=2 / 1) ; y$ axis - absolute values of transferrin absorbance inhibition for a molar ratio of interaction $[$ complex $] /[$ transferrin $]=2 / 1$ : 1 - [transferrin]/[Ru-cpx]; 2 - [transferrin]/[Ru-nf]; 3 - [transferrin]/ [Ru-oflo]; 4 - [transferrin]/[Ru-pip]; 5 - [transferrin]/[Ru-levo]

centual variation of the absorbances was as follows: Ru-pip $>$ Ru-nf $>$ Ru-oflo $>$ Ru-levo $>$ Ru-cpx.

When using the molar ratio [complex]/[transferrin $]=8 / 1$ it was observed a decrease of the UV absorbance of human serum transferrin, in vitro. The procentual dynamics of the absorbances was as follows: Ru-pip $>$ Ru-nf $>$ Ru-levo $>$ Ru-oflo $>$ Ru-cpx.

Our further studies will focus on other critical drug development issues, like testing of these complexes and on in vivo tumor models.

Conclusions. The experimental results regarding the interaction of the studied ruthenium complexes with human serum transferrin have revealed a series of important aspects:

All the studied complexes interact in vitro with transferrin, fact proved by the decrease of transferrin UV absorbance due to the contact with these compounds, in all concentrations;

The ruthenium complex with pipemidic acid intensively reduces the transferrin UV absorbance, followed by the ruthenium complex with norfloxacin;

The weakest interaction complex-transferrin has been registered in the case of ruthenium-ciprofloxacin;

The molar ratio [complex]/[transferrin] $=8 / 1$ has presented the strongest UV detectable interactions, in the chosen experimental conditions, for all the evaluated complexes. 


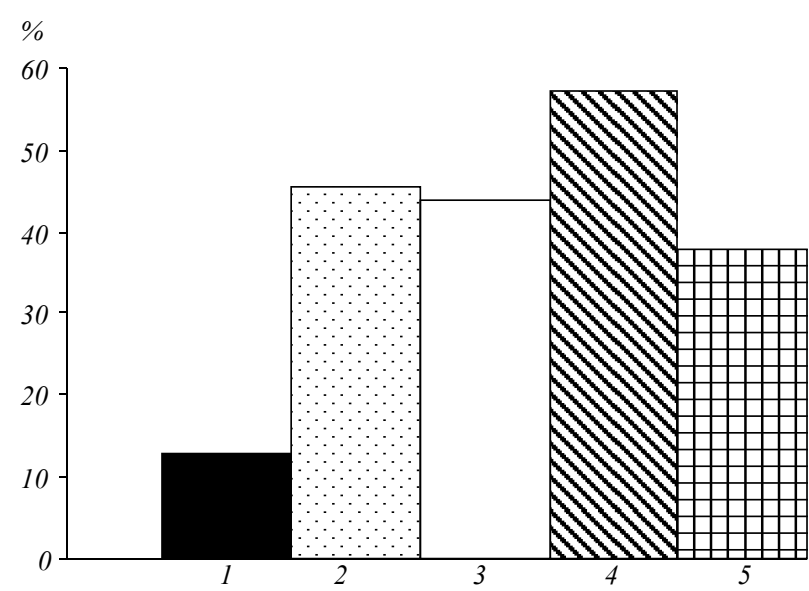

Fig. 5 Dynamics of human serum transferrin UV absorbance after the interaction with the studied complexes (molar ratio [comp- lex]/[transferrin $]=8 / 1) ; y$ axis - absolute values of transferrin absorbance inhibition for a molar ratio of interaction [complex]/[transferrin] $=8 / 1$ : 1 - [transferrin]/[Ru-cpx]; 2 - [transferrin]/[Ru-nf]; 3 - [transferrin] $/$ [Ru-oflo]; 4 - [transferrin]/[Ru-pip]; 5 - [transferrin]/[Ru-levo]

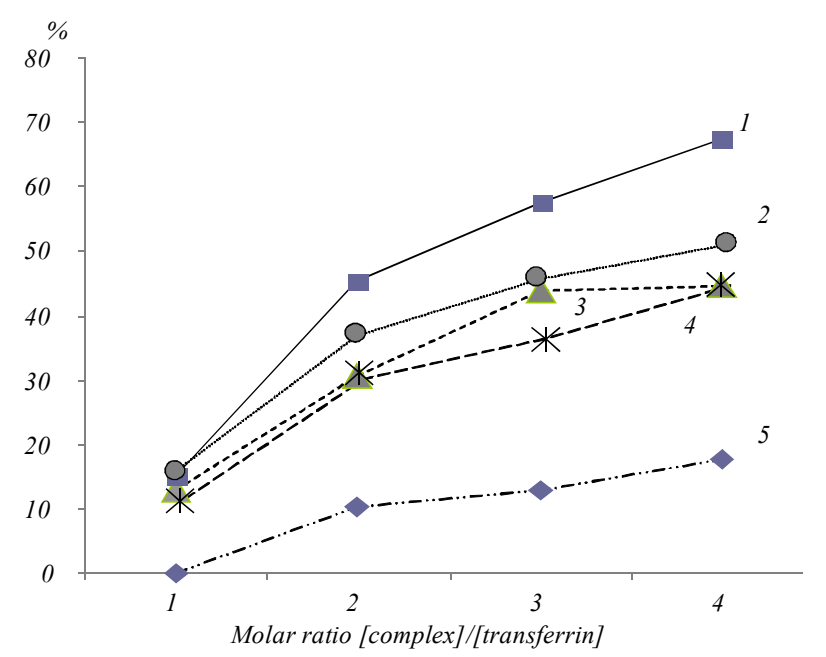

Fig. 6 Comparative procentual values of human serum transferrin UV absorbance after binding with the studied ruthenium complexes; $y$ axis - absolute values of transferrin absorbance inhibition after complex binding; 1 - [transferrin]/[Ru-cpx]; 2 - [transferrin]/[Ru-nf]; $3-$ [transferrin]/[Ru-oflo]; 4 - [transferrin]/[Ru-pip]; 5 - [transferrin] [Ru-levo]

Acknowledgements. This work was partially supported by the PNII grant nr. 61048/2007 of the Romanian Ministry of Education and Research.

\section{А. Л. Арсене, В. Уйварозі, Н. Мітреа, С. М. Драгой, А. Ніколае}

Зв'язувальні властивості деяких нових комплексів рутенію (III) 3 сироватковим трансферином людини

\section{Резюме}

Мета. Останніми роками трансфериновий иикл викликає посилений інтерес як перспективна система цільової доставки протипухлинних препаратів безпосередньо в пухлину. Неопластичні клітини потребують багато заліза, через що експресують велику кількість трансферинових рецепторів. Внаслідок иього кон'югати трансферину здатні насамперед взаємодіяти з раковими клітинами. Цю стратегію у наш час використовують для пошуку нових протиракових препаратів. Останні дані демонструють, що сполукам рутенію (III) притаманні протипухлинні і антиметастатичні ефекти завдяки їхній афінності до важливих біомолекул (таких як трансферин). Методи. У статті представлено трансферин-зв 'язувальні властивості деяких нових комплексів рутенію (III) загальною формулою $\mathrm{RuL} \mathrm{L}_{2}(\mathrm{DMSO}){ }_{m} \mathrm{Cl}_{3} \cdot n \mathrm{H}_{2} \mathrm{O}$ ((Ru-nf) L: норфлоксачин (nf), $m=1, n=$ =1; (Ru-cpx) L: uзипрофлоксацин (cpx), $m=2, n=2$; (Ru-of) L: офлоксаиин (oflo), $m=1, n=1$; (Ru-levo) L: левофлоксацин (Levo), $m=2, n=8$; (Ru-pip) L: піпемідинова кислота (pip), $m=$ $=1, n=2$, DMSO: диметилсульфоксид). Ми вивчали взаємодію in vitro uих лігандів з трансферином людини методом спектроскопії для одержання адуктів з високою селективністю до ракових клітин. Результати і висновки. Всі досліджувані комплекси взаємодіють з сироватковим трансферином людини, молярне співвідношення [комплекс]/[трансферин] значно впливає на зв'язувальні властивості. Найкращу взаємодію між аналізованими комплексами і трансферином відмічено при молярному співвідношенні 8:1, а також для Ru-pip i Ru-nf.

Ключові слова: комплекси рутенію (III), трансферин.

\section{А. Л. Арсене, В.Уйварози, Н. Митреа, С. М. Драгой, А. Николае}

Связывающие свойства некоторых новых комплексов рутения (III) с человеческим сывороточным трансферрином

Резюме

Цель. В последние годы трансферриновый цикл вызывает повыменный интерес как перспективная система иелевой доставки противоопухолевых препаратов непосредственно в опухоль. Неопластические клетки испытывают высокую потребность в железе и, следовательно, экспрессируют много трансферриновых реиепторов. Вследствие этого конъюгаты трансферрина способны преимущественно взаимодействовать с раковыми клетками. Эту стратегию в настоящее время используют для поиска новых противораковых препаратов. Последние данные показывают, что соединения рутения (III) обладают противоопухолевым и антиметастатическим эффектами благодаря их аффинности к важным биомолекулам (таким как трансферрин). Методы. В статье представлены трансферрин-связывающие свойства некоторых новых комплексов рутения (III) с общей формулой $\mathrm{RuL}_{2}(\mathrm{DMSO}){ }_{m} \mathrm{Cl}_{3} \cdot \mathrm{nH}_{2} \mathrm{O}$ ((Ru-nf) L: норфлоксацин (nf), $m=1, n=1$; (Ru-cpx) L: изипрофлоксачин (срx), $m=2, n=2$; (Ru-of) L: офлоксаиин (oflo), $m=1$, $n=1$; (Ru-levo) L: левофлоксаиин (Levo), $m=2, n=8$; (Ru-pip) L: пипемидиновая кислота (рір), $m=1, n=2$, DMSO: диметилсульфоксид). Мы изучили взаимодействие in vitro этих лигандов с человеческим трансферрином методом спектроскопии для получения аддуктов, обладающих хорошей селективностью к раковым клеткам. Результаты и выводы. Все исследуемые комплексы взаимодействуют с человеческим сывороточным трансферрином, молярное соотношение [комплекс]/ [трансферрин] сильно влияет на связывающие свойства. Наилучшее взаимодействие между изучаемыми комплексами и трансферрином отмечено при молярном соотнотении 8:1, а также для Ru-pip и Ru-nf.

Ключевые слова: комплексы рутения (III), трансферрин. 


\section{REFERENCES}

1. Singh $M$. Transferrin as a targeting ligand for liposomes and anticancer drugs // Curr. Pharm. Des.-1999.-5, N 6.-P. 443451.

2. Wagner E., Curiel D., Cotten M. Delivery of drugs, proteins and genes into cells using transferrin as a ligand for receptor-mediated endocytosis // Adv. Drug. Deliver. Rev.1994.-14, N 1.-P. 113-135.

3. Sun H., Li H., Sadler P. J. Transferrin as a metal ion mediator // Chem. Rev.-1999.-99, N 9.-P. 2817-2842.

4. Srivastava S. C., Mausner L. F., Clarke M. J. Radioruthenium-labeled compounds for diagnostic tumor imaging // Prog. Clin. Biochem. Med.-1989.-10.-P. 111-149.

5. Clarke M. J., Zhu F., Frasca D. R. Non-platinum chemotherapeutic metallopharmaceuticals // Chem. Rev.-1999.-99, N 9.P. 2511-2534.

6. Mestroni G., Alessio E., Sava G., Pacor S., Coluccia M., Boccarelli $A$. Water-soluble ruthenium(III)-dimethyl sulfoxide complexes: chemical behaviour and pharmaceutical properties // Met. Based Drugs.-1994.-1, N 1.-P. 41-63.

7. Alessio E., Mestroni G., Bergamo A., Sava G. Ruthenium antimetastatic agents // Curr. Top. Med. Chem.-2004.-4, N 15.P. 1525-1535.

8. Lipponer K. G., Vogel E., Keppler B. K. Synthesis, characterization and solution chemistry of trans-indazoliumtetrachlorobis(indazole) ruthenate(III), a new anticancer ruthenium complex. IR, UV, NMR, HPLC investigations and antitumor activity. Crystal structures of trans-1-methyl-indazoliumtetrachlorobis-(1-methylindazole)ruthenate(III) and its hydrolysis product trans-monoaquatrichlorobis-(1-methylindazole)ruthenate(III) // Met. Based Drugs.-1996.-3, N 5.-P. 243-260.

9. Hartinger C. G., Zorbas-Seifried S., Jakupec M. A., Kynast $B$., Zorbas H., Keppler B. K. From bench to bedside - preclinical and early clinical development of the anticancer agent indazolium trans-[tetrachlorobis $(1 \mathrm{H}$-indazole)ruthenate(III)] (KP1019 or FFC14A) // J. Inorg. Biochem.- 2006.100, N 5-6.-P. 891-904.

10. Vilaplana-Serrano R., Basallote M. G., Ruiz-Valero C., Gutierrez-Puebla E., Gonzalez-Vilchez F. Synthesis and X-ray structural study of a novel ruthenium (III)-ethylenediaminetetraacetate complex. The first compound showing an unusual coordination site for a carboxylic (glycine) group // J. Chem. Soc. Chem. Commun.-1991.-N 2.-P. 100-101.
11. Frasca D. R., Gehrig L. E., Clarke M. J. Cellular effects of transferrin coordinated to // J. Inorg. Biochem.-2001.-83, N 23.-P. 139-149.

12. Messori L., Kratz F., Alessio E. The interaction of the antitumor complexes $\mathrm{Na}$ [trans-RuCl4(DMSO)(Im)] and $\mathrm{Na}$ [transRuCl4(DMSO)(Ind)] with apotransferrin: a spectroscopic study // Met. Based Drugs.-1996.-3, N 1.-P. 1-9.

13. Bergamo A., Messori L., Piccioli F., Cocchietto M., Sava G. Biological role of adduct formation of the ruthenium(III) complex NAMI-A with serum albumin and serum transferring // Invest. New Drugs.-2003.-21, N 4.-P. 401-411.

14. Kratz F., Keppler B. K., Messori L., Smith C., Baker E. N. Protein-binding properties of two antitumour Ru(III) complexes to human apotransferrin and apolactoferrin // Met. Based Drugs.1994.-1, N 2-3.-P. 169-173.

15. Piccioli F., Sabatini S., Messori L., Orioli P., Hartinger Ch. G., Keppler B. K. A comparative study of adduct formation between the anticancer ruthenium(III) compound HInd trans-[RuCl4 (Ind)2] and serum proteins // J. Inorg. Biochem.-2004.-98, N 6.-P. 1135-1142.

16. Gonzalez V. F., Vilaplana R., Blasco G., Messori L. Solution studies of the antitumor complex dichloro 1,2-propylendiaminetetraacetate ruthenium (III) and of its interactions with proteins // J. Inorg. Biochem.-1998.-71, N 1-2.-P. 45-51.

17. Badea M., Olar R., Marinescu D., Uivarosi V., Iacob D. Thermal decomposition of some biologically active complexes of ruthenium (III) with quinolone derivatives // J. Therm. Anal. Calorim.-2009.-97, N 2.-P. 735-739.

18. Badea M., Olar R., Marinescu D., Uivarosi V., Nicolescu T. O., Iacob $D$. Thermal study of some new quinolone ruthenium(III) complexes with potential cytostatic activity // J. Therm. Anal. Calorim.-2010.-99, N 3.-P. 829-834.

19. Rau G., Mogosanu G.-D., Stanciulescu C. E. Synthesis and characterization of some novel azoderivatives // Farmacia.-2009.57, N 5.-P. 648-658.

20. Jurca T., Marian E. Scanning electronic microscopy study of new pyrazinamide compounds with metallic ions // Farmacia.2009.-57, N 2.-P. 247-253.

UDC611.018.54 + 661.896 Received 10.01.11 